\title{
Abdullah Akhmedov and the Phenomenon of Author in Soviet Modernism
}

\author{
Ruslan Muradov ${ }^{1, *}$
}

\author{
${ }^{1}$ The Turkmen Union of Architects, Ashgabat, Turkmenistan \\ *Corresponding author. E-mail: turkmenica@yandex.ru
}

\begin{abstract}
The problem of authorship remains the least studied topic in the history of Soviet architecture, not in the sense of attribution of specific projects and structures, but as a topic of function-author. This article deals with the emergence of the phenomenon of the architect-author as an independent person, free in his or her work. It became possible only in the architecture of 1960s-1970s, today called Soviet Modernism. The background and death of the author in postmodernism are shown on the example of the work of the chief architect of Ashgabat, Academician Abdullah Akhmedov.
\end{abstract}

\section{Keywords: Central Asia, Ashgabat, vernacular, the Thaw period, architecture of Soviet Modernism,}

regionalism

\section{INTRODUCTION}

For centuries, the monumental architecture of Islamic countries has developed through the gradual evolution of the canon, in which the personality of an individual master was dissolved. To the best of his skill and talent, he could only reproduce stereotypes, improving or simplifying designs, or improvising with a certain set of ornamental elements. The building canon and traditional architectural morphology of medieval Central Asia were thoroughly studied as early as in the Soviet period. First of all, these are works by Mitkhat Bulatov (1907-2004) on geometric harmonization, and Nadezhda Smolina on symmetry as a form of architectural thinking. But in the twentieth century, a sharp change took place. Global changes in the world caused by social and political reasons, as well as scientific and technological progress, did not leave aside the provinces of the Russian Empire. The Turkestan Region, inhabited mainly by Moslems, was transformed into Soviet republics of Central Asia in the 1920s; it was involved in the general process that changed the character of the local building culture very quickly and radically.

In the late nineteenth century, having lost their former identity, cities and villages of the region underwent Europeanization, which was expressed in construction of colonial settlements with regular plans. At first, they were enclaves that were in no way connected with old settlements of autochthons either structurally or genetically. Then, already in the twentieth century, in the process of massive introduction of industrial methods of construction, they took a dominant position, virtually destroying the remnants of indigenous areas and vernacular architecture. Stylistically, new 'socialist' buildings were in the general trend of Soviet architecture and differed little from synchronous buildings in the Caucasus or Siberia. The conservatism of Europeanstyle colonial houses of 1920 s was replaced with a rather short Constructivist revolt against tradition; from 1930s there was a return to pseudo-Classicism (the notorious Stalinist Imperial style and reanimation of historical motives); in 1960s there was a triumph of international style and Modernism. And finally, in 1990s, a new Eclecticism was introduced in the Central Asian Region; in the words of Philipp Meuser, it is "a whimsical mixture of antique colonnades, oriental domed architecture and mirrored curtain facades" [1]. Those changes were not a consequence of any natural artistic processes of an evolutionary nature, which got impetus from individual masters, creative groups, and conceptual schools. As Andrei Ikonnikov (1926-2001) believed, "a centralized state and centralized types of construction contribute to the prosperity of some trends in architecture and hinder the development of others" [2].

The architecture of Modernism as a whole is free from any historical heritage and requirements of religion, a priori turning architect into a demiurge, a true creator of the world. But the world was in not ready to recognize such a role of architect - at any level of his creativity. And when in the twentieth century several generations of the so-called stars of the world architecture appeared in open societies, in the U.S.S.R. and its satellites such situation was out of question. Rejecting personalism as one of manifestations of 'bourgeois philosophy', totalitarian states and 
autocracies leave no room for the normal development of artistic culture. Therefore, there are not and cannot be any 'famous architects'. Construction activity, as in the Middle Ages, is anonymous, and the concepts of 'author', and 'copyright' turn into an empty phrase.

Nevertheless, despite such an impersonal nature of totalitarianism, in 1960s, the Soviet Union became a full-fledged player in the world architectural system [3]. This fact is clearly demonstrated by the works by Abdula Akhmedov (1929-2007), who, in 1961-1987, served as Chief Architect of Ashgabat and became the most famous figure in the architecture of the region. During his lifetime, he received almost all the awards and honorary titles on which a Soviet architect could count on. Much has been written about his main creation - the building of the Karl Marx State Library in Ashgabat - and is still being written today [4]. He made that peripheral Soviet city a haven for avant-garde sculptors persecuted in Moscow - such as Ernst Neizvestny and Vadim Kosmachev - who represented alternative forms of independent art and in the preemigrant period in collaboration with Akhmedov were able to carry out some of their best monumental works there. One can hardly doubt the purely authorial nature of these works, although their path from conception to implementation turned out to be much more tortuous than it was in the West in the same era.

\section{THE BIRTH OF THE AUTHOR DURING THE THAW PERIOD (OTTEPEL')}

Despite the fact that some medieval objects of monumental Islamic architecture have preserved epigraphic autographs of master builders, in general, vernacular sphere, as well as folklore, excluded the very possibility of authorship. "The figure of the author belongs to modern times," Roland Barthes argued in his essay 'The Death of the Author'. According to him, the concept of the author was formed as the European society discovered the dignity of the individual, or, in a higher syllable, "the human person" [5]. European methods of construction, which began to be introduced in Central Asia after the Russian conquest in the second half of the nineteenth century, were already based on project documentation. The designs of all buildings without exception - from fortifications to religious ones - were developed, approved and sent first from St. Petersburg, and then, after the establishment of the positions of city and regional architect under the local military administration, in a number of cases were made on the spot. But is it appropriate to speak in this case about authorship?

Firstly, projects for Turkestan were made, as a rule, not by professional architects, but by military and civil engineers or even construction technicians under the local administration on the basis of auxiliary albums containing ready-made elements of structures and finishing components. They did not provide any field for free creativity, and in relation to iconic objects Orthodox churches - there was a strict directive to preserve their national identity, that is, the 'Russian style'.

Secondly, the colonial buildings for the most part remained anonymous - even archival research rarely makes it possible to establish the specific names of the authors, and in the former Trans-Caspian region, which geographically almost coincides with the borders of modern Turkmenistan, not a single object of that period has convincing personal attribution.

Finally, neither the Russian Empire nor the U.S.S.R. joined the Bern Convention of 1886 for the Protection of Literary and Artistic Works, which, in 1908, was supplemented with the phrase "works of architecture", and Russian domestic legislation did not at all consider architectural projects and structures as objects of copyright [6].

Little has changed in this aspect after the establishment of the Soviet power. Stalin's thesis about culture "national in form and socialist in content" for many years set a system of coordinates in which all Soviet architects were forced to work. The formula invented by Stalin, according to the historian of architecture Dmitry Khmelnitsky, allowed any party official to manage architecture without requiring any professional knowledge from him. Moreover, professional knowledge was evaluated much lower than a mystical ability to distinguish ideological from nonideological characteristics of a party professional. The versatility of the method was tested by the time, when in 1954 Khrushchev casually brought down the entire system of Stalinist artistic preferences. The style has been changed, but the method as an instrument of management resisted and did not require fundamental corrections in the wording [7].

In the Soviet Union, which was a conglomerate of completely different cultures, there was a total unification, which affected architecture among the first spheres. And above all, the author was killed as an independent person, free in his work. Finally, authorship presupposes the existence of a property regime, rights to one's creation, and this is what all Soviet architects, even the most titled ones, were deprived of

After 1929, the conditions for the functioning of architecture, of course, did not leave any chances for either young specialists or academicians to do what their colleagues in the West could do. How did it happen that as a result of the Khrushchev's reform, which was absolutely pernicious for architecture as a high art, on extremely unfavorable soil and in a rather harsh ideological climate, not only works of authorship appeared, which even today, from a distance of half a 
century, are perceived by most critics as undoubted artistic achievements? The work by Abdula Akhmedov of his Ashgabat period helps to understand this paradox.

Since 1954, Akhmedov, having received the qualification of architect in Baku, began to work independently in Ashgabat, but only five years later, having mastered the language of international architecture, he issued the first projects in a new style, cleared of 'excesses' and completely corresponding to the categories of lightness that had become a common norm [8]. A year later, he was entrusted with the design of the State Library of the Turkmen S.S.R. - that object turned into his opus magnum and gained international fame in the professional community.

"The Palace of Congresses in the Moscow Kremlin became a paradigm of the Soviet official building of the sixties," wrote Andrei Ikonnikov [9]. Built in just a few months in 1961, it served as the prototype for many large buildings in the capitals of the Soviet republics and for their party leaders immediately turned into a new aesthetic ideal. That is why Akhmedov's project was accepted and supported: the new fashion, approved by Khrushchev himself, should be encouraged, and although it was absolutely alien to the personal tastes of the leaders of the Turkmen S.S.R., the political situation was more important to them. The hardened party bureaucrats had no choice but to approve and accept the fashionable modernist project for execution.

Akhmedov and many of his peer colleagues were quite sensitive artists; they lived in unison with their time and became the exponents of its spirit, which in the Soviet Union had its own unique flavor, due to the atmosphere of the 'Thaw', and that incredible leap from a very recent gloomy past into a bright, as it was then readily believed, the future. It seemed to them, in the words of Reiner Banham, that "they represent an heroic attempt to take the future in hand and cast it in an architectural mold" [10]. The triumph of the new, transparent architecture, which emerged from the same workshops where pseudo-classical works were still yesterday, was to a certain extent, of course, sanctioned 'from above', but Khrushchev, starting a fight against 'excesses', had hardly any idea what kind of Jinn he had released.

\section{THE SHORT ERA OF ASHGABAT MODERNISM}

The Ashgabat buildings by Akhmedov and his associates appeared just half a century after the world's first serious experiments in using reinforced concrete as the main building material and means of architectural expression (including without cladding), which were undertaken in Catalonia by Antonio Gaudí, and then in France by Tony Garnier and Auguste Perret. Le
Corbusier studied with the latter and brought from his workshop admiration for the plastic properties of reinforced concrete structures. Subsequently, he successfully applied them in a number of his own buildings. The new material allowed him to formulate the principles of functionalism, which became the basis of the international style in the late 1920s. It quickly spread, first in Europe, then in the U.S.A., South America, and Japan. With the beginning of Pier Luigi Nervi's activities in Italy, the form-shaping possibilities of reinforced concrete were revealed even more, and their special poetic understanding was demonstrated in Brazil by Oscar Niemeyer already in the middle of the century. All this, of course, became the cultural layer on which Akhmedov's projects arose in Ashgabat. He became an adherent of 'rough concrete', naturally, under the influence of Le Corbusier.

It was the plastic capabilities of monolithic concrete that Akhmedov used in full scale. Already in the mid1960s, according to critics, he was able to define his own problems, the meaning of which was seen in the adaptation of architecture to natural conditions, local history, based on sheer reminiscences. The emergence of a professional school in Turkmenistan with such attitudes and practical experience quickly brought it to the forefront of the Soviet Union.

Speaking about the most famous work by Akhmedov, Canadian art critic Boris Chukhovich drew attention to the fact that there "we get a clear sense of a rethinking of Corbusier s Indian experiments with their use of concrete, lapidary details, decorative sun blinds, complexly shaped internal courtyards, and so on. This rethinking was exclusively creative and courteous - and in terms of functionality and contextual precision was even more convincing than many of the original buildings. Everyone who knows the library in Ashgabat notes its absolute aptness in its urban and natural context, as well as the highly original concept of a 'building without boundaries' that seems to grow out of the surrounding space with its street furniture, gradually drawing visitors inside. While noting all this, architecture critics of the time did not focus on the international context in which this experiment was rooted, but on local traditions... The case of Akhmedov is as paradoxical as it is typical, given that he firmly resisted the temptation to exploit 'national traditions'", [11].

Boris Chukhovich focuses on the fact that the Central Asian "Modernism of the periphery" could not abstract from such an external referent as the 'Ancient East'. But Akhmedov openly neglected the ideological principles of the 'correct' Soviet architecture, often repeating that the architect should create not in the national, but in his own style. He liked to quote the words of Kenzo Tange that the national tradition originates from the climate and natural conditions, 
while the space itself is international. As his younger Moscow colleague Sergei Kiselev noted, "Akhmedov did not adapt to the old context, but created a new one. He could afford to be bold." [12]

In his projects there are no hints of a desire to surprise and amaze, but there is a desire to express his attitude, of course, absolutely sixties with its inherent democracy and political leftism. The aesthetics of Modernism and the tastes of totalitarian power are seemingly absolutely incompatible. But the phenomenon of the Soviet 1960s is that the living sprouts of Modernist culture nevertheless made their way through the thick layer of the eternal, as many believed, glaciation.

Personalism dominates in Akhmedov's work, a personal manner of interpreting each project task. In his work, as in the works by his famous contemporaries in the West - such as Louis Kahn, Philip Johnson, or James Sterling - as Vyacheslav Glazychev put it, the author's handwriting is clearly offered to the viewer (and the customer) as a general cultural value: "Everyone is a creator of his own style! - so it would be possible to conditionally define the motto of the second generation of 'modern architecture' "[13]. Of course, they were not the 'founders of discursiveness' according to Michel Foucault, but they made such architecture possible in the mass consciousness, in the work of other, lesser-known contemporaries, and therefore their function of authors goes far beyond their own creativity.

Akhmedov was not only an administrative, but also a creative leader of Ashgabat architects, his direct and indirect influence is felt in every project implemented in this city during the quarter of a century, when he headed the architectural service at the mayor's office. He filtered all project products, rejecting some and approving others. As a result of this inherently authoritarian approach, Ashgabat avoided 'Tashkentisation' and got its own face. And if we are trying to squeeze the creativity of the Ashgabat architects of that period into some marked cell, into one of the world trends, then it will rather be regionalism. They took inspiration from well-defined loci. Philip Wilkinson put it well: "All modern architects worth the name absorbed and transformed influences from specific localities, adapting these influences in the process but leaving some trace of them in their buildings, too" [14].

One of the obvious sources of inspiration for Akhmedov when creating the image of the Ashgabat Library was the medieval clay castle the Greater Kyz Kala in Merv, which he knew well from childhood, as he lived nearby. But in this monument, which has no clear attribution at all - neither by age, nor by purpose, nor by belonging - there is certainly nothing national. And if we talk about the fact that Kyz Kala is guessed at the basis of the image of the Library, as noted by the American journalist Helen Young Chang [15], then it should be added that this is still only a local prehistory of an absolutely Modernist project in its essence, and not an associative connection with certain national traditions, as it was customary to write about this building in Soviet times.

The architecture of Soviet Modernism can be roughly divided into two categories: public buildings constructed according to the author's projects - with a pronounced imagery; and typical residential buildings products of industrial production. Thirty years after the end of the era of Modernism, the second group as a whole was still preserved, despite the physical wear and tear and degradation of infrastructure, while the objects of the first group, which once constituted the pride and glory of Soviet cities, were demolished or passed under such reconstruction, after which made them hardly recognizable. What seemed to be the architecture of the future for the new post-Soviet regime became the personification of the unwanted Soviet past. This is understandable: a different political regime, a new ideology begin to assert itself primarily by denying the previous era. And Modernism is now not just rejected, but completely removed from the urban context - as if it has never existed. A kind of hybrid of passéism with kitsch blossomed in the vacant space, filling the architectural space with a completely different meaning.

Modern Ashgabat serves as a vivid example of how the new government gets rid of the legacy of the recent past and is actively generating a completely different architecture. Of course, this is happening not only in Ashgabat. It doesn't matter who initiated the demolition of such striking Modernist buildings as the Palace of Youth in Yerevan or the House of Cinema in Tashkent - private owners or government officials. It is important that, in their opinion, those and many other objects of Soviet Modernism demolished over the past twenty years in the CIS countries did not represent any value.

\section{CONCLUSION}

The problem with Modernism (or crisis, as its critics say) is that, given the democratic choice, it invariably loses in favor of pseudo-Classical trash. And now, when architectural Modernism, in essence, remained in the past, the time has come for theoretical reflection on what it was - an aesthetically autonomous phenomenon or something not of professional interest, as the historian of the Soviet avant-garde Selim Khan Magomedov believes. According to Vladimir Paperny, this is not interesting even for theoretical analysis [16]. Of course, not all modern researchers agree with such extreme estimates. They understand that the short epoch of Soviet Modernism was the time of birth of the author's architecture, when the personality of the 
master, his role in the architectural process came out of the dictates of totalitarian power. This gaining of shortterm freedom turned into the fact that individual architects - such as Abdulah Akhmedov in Ashgabat, Felix Novikov in Moscow, Jim Torosyan in Yerevan, Sergo Sutyagin in Tashkent, and many of their peers in other cities of the country - managed to create their own extraordinary structures.

The author is a stylistic unity, Michel Foucault repeated more than once, emphasizing the prospect of abolishing the author. According to this logic, if an author suddenly changes his handwriting, he, as it were, ceases to be himself, ceases to be the one for whom we took and valued him. He becomes unrecognizable, indistinguishable from the general mass. Alas, this happened to Akhmedov in 1990s, in the Moscow period of his work: in a different context, succumbing to the influence of Postmodernism, pressure from developers, he became different. And he stopped being the author.

\section{References}

[1] Philipp Meuser, Building one's 'I'. In search of national identity, in: Project Russia, No 30, 2003/4, pp. 36-38.

[2] Alessandra Latour, Birth of a Metropolis. Moscow 1930-1955. Recollections and Images. Moscow: Iskusstvo - XXI vek Publ., 2002, p. 96.

[3] Stephane Gaessler, Soviet Architecture of the 1960s: Between Internationalization and Regionalization, in: Advances in Social Science, Education and Humanities Research, vol. 324. AHTI 2019, p. 34

[4] Yulia Kosenkova, The Experience of a "Different"Architecture. The Ashgabat library of Abdullah Akhmedov in the context of Soviet architecture of the 1970s (Opyt 'drugoi' arhitektury. Ashkhabadskaya biblioteka Abduly Ahmedova v kontekste sovetskoi arhitektury 1970-h godov), in Architectural Heritage (Arhitekturnoe nasledstvo), issue 46. Moscow: Stroyizdat, 2006, pp. 318-324 [in Russian]; Ruslan Muradov, Homo Liber. Abdullah Akhmedov in Ashgabat, in: Soviet Modernism 19551991. Unknown History. Wien - Zürich: Park Books, 2012, pp. 246-255.

[5] Roland Barthes, Le bruissement de la langue. Paris: Seuil, 1984, p. 61-62 [in French]

[6] K.D. Shestakova, On the subject of copyright in architecture (K voprosu ob ob'ekte avtorskogo prava v oblasti arhitektury), in: Vestnik Sankt-Peterburgskogo universiteta, seriya 14, 2010, issue 4, p. 27 [in Russian].

[7] D. Khmelnitsky, The Architecture of Stalin. Psychology and Style (Arhitektura Stalina. Psihologiya i stil'). Moscow: Progress - Traditsia Puvl., 2007, p. 275 [in Russian].

[8] Olga Kazakova, The concept of modernity in the architecture of the Thaw era - from ethics to aesthetics (Ponyatie 'sovremennost' v arhitekture 'ottepeli' - ot etiki k estetike), in: The Aesthetic of the Thaw period: new features in architecture, art and culture (Estetika 'ottepeli'. Novoe v arhitekture, iskusstve, kul'ture). Moscow: ROSSPEN Publ., 2013, p. 169 [in Russian].

[9] Andrey Ikonnikov, The Architecture and History (Arhitektura i istoriya). Moscow: Arhitectura Pibl., 1993, p. 202 [in Russian].

[10] Reyner Banham, Age of the Masters: A Personal View of Modern Architecture. New York - London: Harper \& Row, 1975 , p. 6
[11] Boris Chukhovich, Building the 'Living East', in: Soviet Modernism 1955-1991. Unknown History. Wien - Zürich: Park Books, 2012, pp. 220-221.

[12] Olga Buharkova, Abdullah Akhmedov as Artist (Abdul Ahmedov - hudozhnik), in: Ogonyok (weekly magazine), 2001, No 43, p.36 [in Russian].

[13] Vjacheslav Glazichev, The Evolution of Creativity in Architecture (Evolyutsija tvorchestva v arhitekture). Moscow, Stroyizdat Publ., 1986, pp. 476-477 [in Russian]..

[14] Philip Wilkinson, 50 architecture ideas you really need to know. New York - London: Quercus Publ., 2010, p. 181.

[15] Helen Young Chang, The Buildings of Socialism, in: The Wall Street Journal, November 15, 2012.

[16] URL:

https://snob.ru/entry/194553/?fbclid=IwAR3gBmWwetl8SmpeP voWWG9-YxIM2aglEgf_gmzhJkKn8C5bWs_330AmBHQ (accessed 26.06.2020) 